\title{
Tubal Stump Pregnancy in ART Patients Two cases of ectopic stump pregnancy after IVF-ET
}

\author{
Di Tucci Chiara*, Schiavi Michele Carlo, Iacobelli Valentina, Donfrancesco Cristina, Piccioni Maria Grazia, Perniola \\ Giorgia, Muzii Ludovico and Benedetti Panici Pierluigi
}

Department of Gynecologic-Obstetrical and Urologic Sciences, Italy

Received: 制: Octobet 22, 2018; Published: 制: November 13, 2018

*Corresponding author: Chiara Di Tucci, Department of Obstetrics and Gynecology, Italy

\begin{abstract}
Ectopic pregnancy (EP) is a complication of pregnancy in which the embryo attaches outside the uterus. The rate of ectopic pregnancy is about 1 and $2 \%$ that of live births, though it may be as high as $4 \%$ among those using assisted reproductive technology (ART). We present two cases of interstitial stump pregnancies in patients who previously underwent salpingectomy for ectopic pregnancies, and a review of the literature. One patient has been treated with methotrexate (MTX) before the removal of the tubal stump, while the second has gone directly to laparoscopic (LPS) surgery. Transvaginal ultrasound examination is essential for early and accurate management of this condition. It should be quickly performed to rule out a stump interstitial pregnancy in women who conceive by ART after bilateral salpingectomy. A correct attitude towards this condition is not yet internationally standardized and both medical and surgical options should be promptly considered.
\end{abstract}

Keywords: Ectopic pregnancy (EP); Assisted reproductive technologies (ART); Tubal stump; Methotrexate (MTX); In vitro fertilization (IVF)

Abbreviations: EP: Ectopic Pregnancy; ART: Assisted Reproductive Technologies; MTX: Tubal Stump Methotrexate; IVF: In Vitro Fertilization

\section{Introduction}

Ectopic pregnancies (EP) represent the most serious complication of the first trimester of pregnancy. In the vast majority of the cases the embryo prematurely implants itself in the fallopian tube before arriving in the uterine cavity. Only in approximately $2 \%$ of the cases EP occur in different regions such as the cervix, the ovary or the abdominal cavity [1-5]. An atypical and insidious severe event is that the embryo migrates from the uterine cavity to the contralateral tube. We report two cases in which the EP occurred in a fallopian stump after in vitro fertilization (IVF) in women subjected to monolateral salpingectomy for a history of ectopic pregnancy. We present also a review of literature about interstitial pregnancies in tubal stump (Table 1) and a review about EP in unusual sites in women with previous salpingectomy (Table 2) [6-10].

Table 1: Review of literature: interstitial pregnancies in tubal stump.

\begin{tabular}{|c|c|c|c|c|c|c|c|c|}
\hline Author & Year & Age & $\begin{array}{c}\text { Gravity } \\
\text { and parity }\end{array}$ & Previous operation history & $\begin{array}{l}\text { Mode of } \\
\text { conception }\end{array}$ & $\begin{array}{l}\text { Gestation, } \\
\text { weeks }\end{array}$ & Management & $\begin{array}{l}\text { Internal } \\
\text { Bleeding }\end{array}$ \\
\hline $\begin{array}{l}\text { Corti,Rolandi } \\
\text { [1] }\end{array}$ & 1964 & 35 & G3,P2 & $\begin{array}{c}\text { Appendicectomy, left salpingo- } \\
\text { oophorectomy for a serous ovarian } \\
\text { cyst }\end{array}$ & Spontaneous & $5+3 d$ & $\begin{array}{c}\text { Subtotal } \\
\text { hysterectomy }\end{array}$ & $50 \mathrm{ml}$ \\
\hline Benzi [2] & 1967 & 27 & G2,P0 & $\begin{array}{l}\text { Righ salpingo- oophorectomy for } \\
\text { ectopic pregnancy }\end{array}$ & Spontaneous & 5 & $\begin{array}{l}\text { Laparotomic } \\
\text { excision of right } \\
\text { tubal stump }\end{array}$ & Poor \\
\hline Krzaniak [3] & 1968 & 30 & $\mathrm{G} 2, \mathrm{P} 2$ & $\begin{array}{l}\text { Appendicectomy, Ovarian } \\
\text { cystectomy }\end{array}$ & Spontaneous & 9 & $\begin{array}{l}\text { Laparotomic } \\
\text { excision of left tubal } \\
\text { stump }\end{array}$ & None \\
\hline Bernardini [4] & 1998 & 36 & G4,P0 & $\begin{array}{c}\text { Appendicectomy, Left salpingo- } \\
\text { oophorectomy for interstitial tubal } \\
\text { pregnancy }\end{array}$ & Spontaneous & $4+5 d$ & $\begin{array}{l}\text { A single i.m. dose of } \\
\text { MTX (100 mg) on } \\
\text { day } 61 \text { of gestation }\end{array}$ & NA \\
\hline
\end{tabular}




\begin{tabular}{|c|c|c|c|c|c|c|c|c|}
\hline \multirow{2}{*}{ Takeda [5] } & \multirow{2}{*}{2006} & 36 & G1,P1 & $\begin{array}{l}\text { Laparotomic right salpingo- } \\
\text { oophorectomy for an ovarian } \\
\text { dermoid cyst }\end{array}$ & Spontaneous & 8 & $\begin{array}{l}\text { Laparoscopic } \\
\text { excision of right } \\
\text { tubal stump }\end{array}$ & $20 \mathrm{ml}$ \\
\hline & & 27 & G3,P2 & $\begin{array}{l}\text { Laparoscopic right salpingo- } \\
\text { oophorectomy for ruptured ovarian } \\
\text { pregnancy }\end{array}$ & Spontaneous & 6 & $\begin{array}{l}\text { Laparoscopic } \\
\text { excision of right } \\
\text { tubal stump }\end{array}$ & $100 \mathrm{ml}$ \\
\hline Milingos [6] & 2008 & 38 & G6,P3 & $\begin{array}{l}\text { Laparoscopic right salpingectomy } \\
\text { and laparoscopic excision of the } \\
\text { right tubal stump }\end{array}$ & Spontaneous & $5+6 d$ & $\begin{array}{l}\text { Laparotomic } \\
\text { excision of right } \\
\text { tubal stump and left } \\
\text { salpingectomy }\end{array}$ & NA \\
\hline Faleyimu [7] & 2008 & 22 & $\mathrm{G} 2, \mathrm{P} 0$ & $\begin{array}{l}\text { Left corneal resection for tubal } \\
\text { pregnancy }\end{array}$ & Spontaneous & 5 & $\begin{array}{l}\text { Laparotomic } \\
\text { left salpingo- } \\
\text { oophorectomy }\end{array}$ & $600 \mathrm{ml}$ \\
\hline Muppala [8] & 2009 & 38 & G3,P1 & $\begin{array}{l}\text { Right salpingectomy for tubal } \\
\text { pregnancy }\end{array}$ & Spontaneous & 6 & $\begin{array}{l}\text { Laparoscopic } \\
\text { cauterisation of } \\
\text { right bleeding tubal } \\
\text { stump }\end{array}$ & $500 \mathrm{ml}$ \\
\hline Sturlese [9] & 2009 & 30 & G1,P0 & $\begin{array}{l}\text { Left salpingo- oophorectomy for an } \\
\text { ovarian dermoid cyst }\end{array}$ & Spontaneous & 6 & $\begin{array}{l}\text { Laparoscopic } \\
\text { excision of left tubal } \\
\text { stump }\end{array}$ & NA \\
\hline \multirow{6}{*}{ Ko PC [10] } & \multirow{6}{*}{2011} & 30 & G2,P0 & $\begin{array}{l}\text { Laparoscopic right salpingectomy } \\
\text { for tubal pregnancy }\end{array}$ & $\begin{array}{l}\text { Ovulation } \\
\text { induction }\end{array}$ & 8 & $\begin{array}{l}\text { Laparoscopic } \\
\text { excision of right } \\
\text { tubal stump }\end{array}$ & $500 \mathrm{ml}$ \\
\hline & & 40 & G7,P4 & $\begin{array}{l}\text { Laparoscopic right salpingectomy } \\
\text { for tubal pregnancy }\end{array}$ & $\begin{array}{l}\text { Ovulation } \\
\text { induction }\end{array}$ & 6 & $\begin{array}{l}\text { Laparoscopic } \\
\text { excision of right } \\
\text { tubal stump }\end{array}$ & $550 \mathrm{ml}$ \\
\hline & & 32 & G4,P0 & $\begin{array}{l}\text { Laparoscopic left salpingectomy for } \\
\text { tubal pregnancy }\end{array}$ & IVF-ET & 8 & $\begin{array}{l}\text { Laparoscopic } \\
\text { excision of left tubal } \\
\text { stump }\end{array}$ & $700 \mathrm{ml}$ \\
\hline & & 30 & G3,P0 & $\begin{array}{l}\text { Laparoscopic bilateral } \\
\text { salpingectomy for right ovarian } \\
\text { pregnancy and left tubal pregnancy } \\
\text { after ICSI }\end{array}$ & ICSI-ET & 7 & $\begin{array}{l}\text { Laparotomic } \\
\text { excision of tubal } \\
\text { stump }\end{array}$ & $2000 \mathrm{ml}$ \\
\hline & & 42 & G3,P1 & $\begin{array}{l}\text { Laparoscopic left salpingectomy for } \\
\text { tubal pregnancy after IUI }\end{array}$ & IVF-ET & 7 & $\begin{array}{l}\text { Laparoscopic } \\
\text { excision of left tubal } \\
\text { stump }\end{array}$ & $20 \mathrm{ml}$ \\
\hline & & 32 & $\mathrm{G} 4, \mathrm{P} 0$ & $\begin{array}{c}\text { Laparoscopic bilateral } \\
\text { salpingectomy for bilateral } \\
\text { hydrosalpinx }\end{array}$ & ICSI-ET & 6 & $\begin{array}{l}\text { Laparoscopic } \\
\text { excision of tubal } \\
\text { stump }\end{array}$ & $200 \mathrm{ml}$ \\
\hline \multirow{2}{*}{$\begin{array}{c}\text { Garavaglia } \\
{[35]}\end{array}$} & \multirow[t]{2}{*}{2012} & 33 & G4 P0 & $\begin{array}{l}\text { partial left salpingectomy and right } \\
\text { total laparoscopic salpingectomy }\end{array}$ & IVF-ET & 3 & $\begin{array}{l}\text { Laparoscopic } \\
\text { resection of the left } \\
\text { tubal stump }\end{array}$ & $100 \mathrm{ml}$ \\
\hline & & 37 & & $\begin{array}{c}\text { bilateral laparoscopic salpingectomy } \\
\text { for bilateral hydrosalpinx }\end{array}$ & IVF-ET & 4 & $\begin{array}{l}\text { laparoscopic right } \\
\text { cornuostomy. }\end{array}$ & NA \\
\hline Shavit T. [36] & 2013 & 35 & G0 P0 & $\begin{array}{l}\text { laparoscopic bilateral salpingectomy } \\
\text { due to hydrosalpinges }\end{array}$ & IVF-ET & 2 & $\begin{array}{l}\text { Laparoscopic } \\
\text { excision of tubal } \\
\text { stump }\end{array}$ & NA \\
\hline \multirow[t]{2}{*}{$\begin{array}{c}\text { Bahareh } \\
\text { Samiei- Sarir } \\
\text { [37] }\end{array}$} & 2013 & 42 & G11 P7 & $\begin{array}{l}\text { Laparoscopic right salpingectomy } \\
\text { for tubal pregnancy }\end{array}$ & Spontaneous & & $\begin{array}{l}\text { monopolar/bipola } \\
\mathrm{r} \text { diathermy plus } \\
\text { tubal ligation on the } \\
\text { left side. }\end{array}$ & $500 \mathrm{ml}$ \\
\hline & & 35 & G8 P2 & $\begin{array}{l}\text { Laparoscopic left salpingectomy for } \\
\text { tubal pregnancy }\end{array}$ & spontaneous & 7 & $\begin{array}{l}\text { Laparoscopic } \\
\text { excision of left tubal } \\
\text { stump }\end{array}$ & $2000 \mathrm{ml}$ \\
\hline $\begin{array}{l}\text { Maruthini et } \\
\text { al [38] }\end{array}$ & 2013 & 33 & G0P0 & $\begin{array}{l}\text { bilateral laparoscopic salpingecto } \\
\text { my for bilateral hydrosalpin x }\end{array}$ & IVF-ET & 6 & $\begin{array}{c}\text { Laparoscopic } \\
\text { then Laparotomic } \\
\text { excision of tubal } \\
\text { stump }\end{array}$ & $300 \mathrm{ml}$ \\
\hline $\begin{array}{l}\text { Nishida M } \\
\text { [39] }\end{array}$ & 2015 & 26 & G4 P1 & $\begin{array}{l}\text { Laparoscopic right salpingectomy } \\
\text { for tubal pregnancy }\end{array}$ & spontaneous & 6 & $\begin{array}{l}\text { Laparoscopic } \\
\text { excision of left tubal } \\
\text { stump, removal of } \\
\text { the gestational sac }\end{array}$ & NA \\
\hline
\end{tabular}




\begin{tabular}{|c|c|c|c|c|c|c|c|}
\hline $\begin{array}{c}\text { Xu Ying et al. } \\
\text { [40] }\end{array}$ & 2016 & 28 & G0 & $\begin{array}{c}\text { bilateral tubal ligation for left } \\
\text { hydrosalpinx and right tubal } \\
\text { occlusion }\end{array}$ & IVF-ET & 7 & $\begin{array}{c}\text { Emergency LPTM } \\
\text { for left ruptured } \\
\text { interstitial } \\
\text { pregnancy }\end{array}$ \\
\hline Souza C. [41] & 2018 & 35 & G3 P1 & $\begin{array}{c}\text { Laparoscopic right salpingectomy } \\
\text { for tubal pregnancy }\end{array}$ & IVF-ET & NA & Right salpingectomy \\
\hline
\end{tabular}

Table 2: Review of literature: EP in unusual sites in women with previous salpingectomies.

\begin{tabular}{|c|c|c|c|c|c|c|c|}
\hline Author & Year & Age & $\begin{array}{l}\text { Gravity and } \\
\text { parity }\end{array}$ & Previous operation history & $\begin{array}{c}\text { Type of } \\
\text { fecondation }\end{array}$ & $\begin{array}{l}\text { Site of ectopic } \\
\text { pregnancy }\end{array}$ & Management \\
\hline Ferland [11] & 1991 & 32 & G4,P0 & $\begin{array}{l}\text { right salpingectomy for tubal } \\
\text { pregnancy }\end{array}$ & IVF-ET & upper retroperitoneum & LPTM \\
\hline Fisch [12] & 1996 & 38 & $\mathrm{G} 2, \mathrm{P} 0$ & $\begin{array}{l}\text { LPS (bilateral salpingectomy } \\
\text { for two tubal pregnancies) }\end{array}$ & IVF-ET & $\begin{array}{l}\text { abdomen (posterior } \\
\text { aspect of the right broad } \\
\text { ligament) }\end{array}$ & LPTM \\
\hline \multirow{3}{*}{ Chen [13] } & \multirow{3}{*}{1998} & 28 & G0 & $\begin{array}{l}\text { LPS (bilateral salpingectomy for } \\
\text { hydrosalpinx) }\end{array}$ & IVF-ET & right uterine cornu & LPTM \\
\hline & & 33 & G1,P0 & $\begin{array}{l}\text { right salpingectomy for hydrosalpinx, } \\
\text { right tuboplasty, successively left } \\
\text { salpingectomy for tubal pregnancy) }\end{array}$ & IVF-ET & left uterine cornu & LPTM \\
\hline & & 32 & G0 & bilateral tuboplasty for tubal disease & IVF-ET & right uterine cornu & LPTM \\
\hline $\begin{array}{c}\text { Dmowsky } \\
{[14]}\end{array}$ & 2002 & 34 & G0 & $\begin{array}{l}\text { LPS (bilateral salpingectomy for } \\
\text { hydrosalpinx) }\end{array}$ & IVF-ET & head of pancreas & LPTM \\
\hline Cormio [15] & 2003 & 30 & $\mathrm{G} 2, \mathrm{P} 0$ & $\begin{array}{l}\text { LPS (bilateral salpingectomy for two } \\
\text { tubal pregnancies) }\end{array}$ & IVF-ET & $\begin{array}{l}\text { abdomen (lower end of } \\
\text { the omentum, adherent } \\
\text { to the uterine fundus and } \\
\text { cecum) }\end{array}$ & LPTM \\
\hline Hsu [16] & 2005 & 29 & G0 & $\begin{array}{l}\text { LPS (bilateral salpingectomy for } \\
\text { hydrosalpinx) }\end{array}$ & IVF-ET & ovary & MTX and LPS \\
\hline $\begin{array}{c}\text { Seshadri et al. } \\
\text { [42] }\end{array}$ & 2010 & 37 & G0 & $\begin{array}{l}\text { Bilateral salpingectomies for two } \\
\text { previous ectopic pregnancies in } 2001 \\
\text { and } 2004\end{array}$ & IVF-ET & ovary & $\begin{array}{l}\text { LPS then } \\
\text { converted to } \\
\text { LPTM }\end{array}$ \\
\hline Cruciani [17] & 2011 & 26 & G0 & $\begin{array}{l}\text { LPS (bilateral salpingectomy for } \\
\text { hydrosalpinx) }\end{array}$ & IVF-ET & ovary & LPS \\
\hline $\begin{array}{c}\text { Sadia } \\
\text { Khandaker et } \\
\text { al. [43] }\end{array}$ & 2015 & 32 & G5P1 & $\begin{array}{l}\text { Right (2007) and left (2009) } \\
\text { salpingectomy for tubal pregnancies }\end{array}$ & IVF-ET & ovary & $\begin{array}{l}\text { LPS then } \\
\text { converted to } \\
\text { LPTM }\end{array}$ \\
\hline $\begin{array}{l}\text { Xu Ying, et al. } \\
\text { [39] }\end{array}$ & 2016 & 28 & G3P0 & $\begin{array}{l}\text { right LPS salpingectomy after two } \\
\text { tubal pregnancies+ left bipolar } \\
\text { salpingectomy for hydrosalpinx }\end{array}$ & IVF-ET & ovary & $\begin{array}{l}\text { Emergency } \\
\text { LPTM }\end{array}$ \\
\hline
\end{tabular}

\section{Case report}

\section{Case 1}

A 36 years old patient referred to our center to ascertain implantation after IVF-ET at the $58^{\text {th }}$ gestational day. The patient had a history of right salpingectomy for GEU. HCG was 2293 IU/L. Obstetrical examination showed a small uterus with no pain. Ultrasound revealed no intrauterine pregnancy, but a gestational sac of $14 \mathrm{~mm}$ adjacent to the right uterine cornu with no signs of embryo viability. Power and color Doppler revealed the presence of the vascular ring with a strong peri-trophoblastic vascular activity (Figures $1 \& 3$ ). After careful counseling it was decided to attempt medical management using the single dose regimen with i.m. MTX $\left(50 \mathrm{mg} / \mathrm{m}^{2}\right)$. Four days after treatment the patient complained strong abdominal pains, low blood pressure and severe anemia. Laparoscopy was carried out and the right tubal stump was removed. Histological examination confirmed the diagnosis of ectopic pregnancy of the right tubal stump. The patient was discharged on day 2 postoperatively and no short- or long-term complications were reported [11-17].

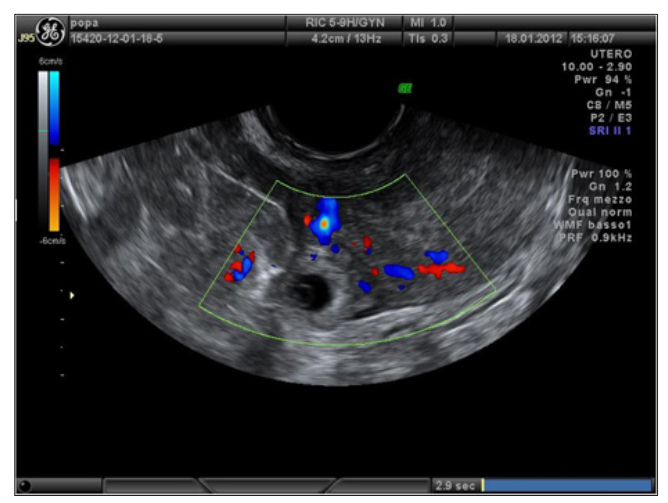

Figure 1: The gestational sac of $13 \times 14 \mathrm{~mm}$ with no signs of embryonic viability in the right interstizial tubal stump at 58 days of pregnancy (Case 1 ). 


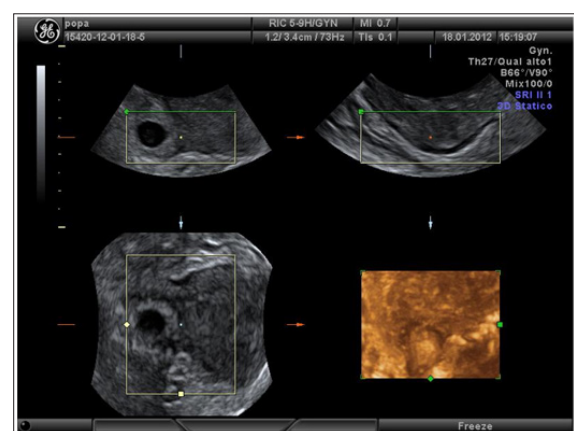

Figure 2: 3D reconstruction of interstitial tubal stump pregnancy (Case 1).

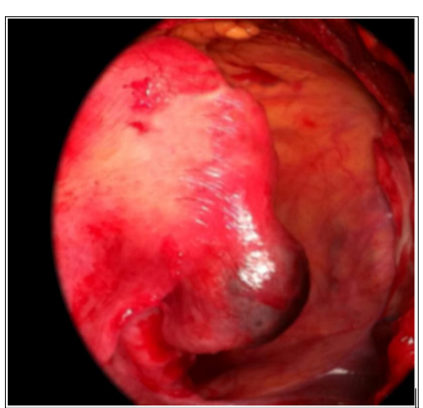

Figure 3: The right tubal stump with the ectopic pregnancy of about $20 \mathrm{~mm}$ in diameter (Case 1).

\section{Case 2}

A 25 years old patient referred to our emergency Department for pain in the right iliac fossa. She was at 7 weeks of gestation after embryo transfer achieved by ICSI. The patient had a history of right salpingectomy for GEU. Pelvic examination revealed pain in the right adnexal area and US showed a gestational sac of $11 \times 10 \mathrm{~mm}$ with no signs of embryonic viability in the right interstitial tubal stump (Figures 4 \& 5) and hemoperitoneum. HCG was 8839 IU/L. The patient was subjected to an emergency laparoscopy and the right tubal stump was removed. Histological examination confirmed the diagnosis of ectopic pregnancy in the right tubal stump. The patient was discharged on day 2 postoperatively and no short- or long-term complications were reported.

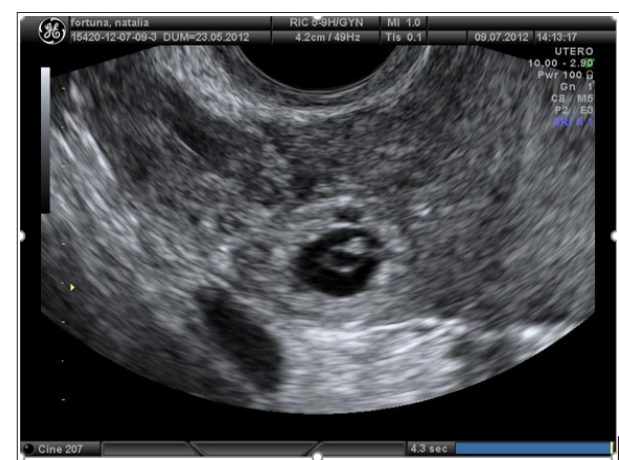

Figure 4: The gestational sac of $11 \times 10 \mathrm{~mm}$ with no signs of embryonic viability in the right interstizial tubal stump pregnancy (Case 2).

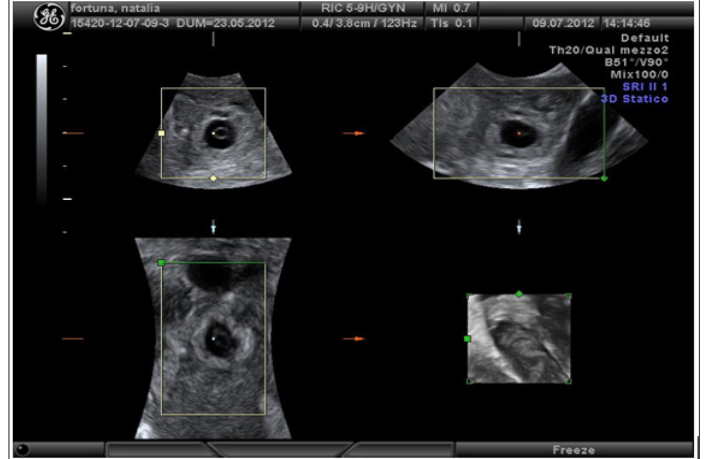

Figure 5: 3D reconstruction of interstitial tubal stump pregnancy (Case 2).

\section{Discussion}

Though the etiology of EP is multifactorial, as many as 50\% of women with an EP have no identifiable risks. Widely accepted risks for EP are not necessarily independent of one another and can vary depending on the population being reported. Risk factors include prior EP, prior tubal and generally pelvic surgery, IUD and a history of pelvic inflammatory disease (PID) [18]. In patients undergoing ART, the chances of an embryo spontaneously implanting at the interstitial tubal segment are higher when compared to a spontaneous pregnancy [19]. Tubal stump pregnancies can occur when the embryo or the oocyte migrate through the uterine cavity or when the oocyte passes through a tubal fistula [3,9]. A review of the literature conducted by Chin et al. [20] reported 22 cases of cornual pregnancies after IVF-ET.

In women with a history of salpingectomy, some cases of unusual implantation sites have been reported. Fisch et al. [12] in 1996 reported a case of an abdominal pregnancy following in vitro fertilization in a women subjected to bilateral salpingectomy. Dmowsky et al. [14] reported a retroperitoneal ectopic pregnancy located in the head of pancreas in a similar patient. Ferland et al. [11] reported a retroperitoneal pregnancy in a patient with previous right salpingectomy secondary to an ectopic gestation. Agarwal et al. [21] studied 26 ectopic pregnancies detected after embryo-transfer during a 7-year period and seven were located in the cornual or tubal stump after prior salpingectomy. Four out of seven women were treated with MTX, but in only one case conservative treatment was successful. The other three cases were tubal implantations, with one rupture during treatment. Chang et al. [22] presented a case of bilateral simultaneous tubal sextuplets pregnancy after in-vitro fertilization-embryo transfer following salpingectomy. Chen et al. [13] described three cases of cornual pregnancies occurring after IVF-ET.

Two of these patients had prior bilateral salpingectomy, whereas another had prior tuboplasty for tubal disease. Nabeshima et al. [23] presented the case of a 38-year-old woman, with a history of left salpingectomy for an ectopic pregnancy, admitted for treatment of another presumed ectopic pregnancy. Surgery was performed for a suspected left cornual pregnancy and with 
laparoscopy the gestational sac was removed; the uterus was preserved. Unilateral and even bilateral salpingectomy cannot prevent subsequent heterotopic pregnancy. Even more catastrophic conditions may occur because the ectopic gestation is always located within the interstitial tubal portion, rather than in the ampullary portion of the fallopian tube [24]. The uterine cornu has an abundant blood supply from branches of the ovarian and uterine arteries and a ruptured cornu can have tragic consequences from sudden and excessive blood loss. For this reason, these pregnancies are generally associated with very high serum HCG levels and the mortality rates for interstitial pregnancy are estimated to be 7-15 times higher than another EP [25].

At the beginning, the traditional treatment for interstitial pregnancy was cornual resection by laparotomy or hysterectomy [26]. In the last decades operative laparoscopy has generally been considered the "gold standard" for the treatment of tubal ectopic pregnancies [27], but medical treatment is viewed with increasing interest. The medical treatment is of particular relevance in the case of infertile patients for whom any avoidance of additional surgical intervention translates into a reduced risk of repeating ectopic pregnancy, in addition to maximal preservation of their future fertility potential. The estimated success rate for medical treatment with methotrexate of interstitial pregnancy is lower than that for treatment of ectopic pregnancies located in the tubal ampulla or isthmus [28]. Although medical therapy can be successful at serum HCG concentrations considerably higher than 3000 IU/l, quality-oflife data suggest that methotrexate is only an attractive option for women with an hCG below $3000 \mathrm{IU} / \mathrm{l} \bigotimes 29-31]$.

In 2016, the Royal College of Obstetricians and Gynaecologists (RCOG) released a new guideline providing evidence-based guidance on the diagnosis and management of ectopic pregnancies [32]. Concerning interstitial or cornual pregnancies, it pointed out that even if a pharmacological approach using methotrexate has been shown to be effective, there is insufficient evidence to recommend local or systemic approach. Moreover, RCOG guideline has confirmed the main role of surgery in the management of cornual pregnancy with conservative, laparoscopic or open surgical methods, and it reported medical therapy with methotrexate and potassium chloride injection as an option prior to later laparoscopic horn excision. Nevertheless, an international consensus on the management of cornual or stump pregnancy is still far, as all the evidence reported in the guideline come from non-analytical studies, such as case reports or are based on expert opinion.

Reviewing the literature, we found only one case of tubal stump pregnancy treated successfully with a single i.m. dose of MTX (100 $\mathrm{mg}$ ) with a serum HCG concentration of $12.470 \mathrm{IU} / \mathrm{ml} \otimes 4]$. The presence of cardiac activity in an ectopic pregnancy is associated with a reduced chance of success following medical therapy and should be considered a contraindication to medical treatment $[32,33]$. Therefore, a similar behavior should be considered for EP of the tubal stump. In conclusion, early transvaginal ultrasound should be considered in women with a history of salpingectomy in order to allow early diagnosis of EP of the tubal stump. Physicians should remember to consider this severe condition when surgically treating conditions such as PID and EP and remove the fallopian tube entirely [34-43].

\section{Disclosure Statement}

The authors declare that there is no conflict of interests regarding the publication of this paper.

\section{References}

1. Corti A, Ronaldi L (1964) Ectopic pregnancy in the site of previous adnexectomy. Osped Maggiore 59: 413-422.

2. Benzi G, Mazza L (1967) Recurrence of ectopic pregnancy in a residual tubal stump after prior adnexectomy for extra-uterine pregnancy. Minerva Ginecol 19(4): 171-178.

3. Krzaniak S (1968) Ectopic gestation in a tubal stump. Postgrad Med J 44: 191-192.

4. Bernardini L, Valenzano M, Foglia G (1998) Spontaneous interstitial pregnancy on a tubal stump after unilateral adenectomy followed by trasnvaginal colour Doppler ultrasound. Hum Reprod 13(6): 1723-1726.

5. Takeda A, Manabe S, Mitsui T, Nakamura H (2006) Spontaneous ectopic pregnancy occurring in the isthmic portion of the remnant tube after ipsilateral adnexectomy: Report of two cases. J Obstet Gynaecol Res 32(2): 190-194.

6. Milingos DS, Black M, Bain C (2008) Three surgically managed ipsilateral spontaneous ectopic pregnancies. Obstet Gynecol 112(2 Pt 2): 458-459.

7. Faleyimu BL, Igberase GO, Momoh MO (2008) Ipsilateral ectopic pregnancy occurring in the stump of a previous ectopic site: a case report. Cases J 1: 343.

8. Muppala H, Davies J (2009) Spontaneous proximal tubal stump pregnancy following partial salpingectomy. J Obstet Gynaecol 29(1): 6970.

9. Sturlese E, Retto G, Palmara V, Dominici RD, Re CL, et al. (2009) Ectopic pregnancy in tubal remnant stump after ipsilateral adnexectomy for cystic teratoma. Arch Gynecol Obstet 280(6): 1015-1017.

10. Ko PC, Liang CC, Lo TS, Huang HY (2011) Six cases of tubal stump pregnancy: complication of assisted reproductive technology? Fertil Steril 95(7): 2432.

11. Ferland RJ, Chadwick DA, O'Brien JA, Granai CO $3^{\text {rd }}$ (1991) An ectopic pregnancy in the upper retroperitoneum following in vitro fertilization and embryo transfer. Obstet Gynecol 78(3): 544-546.

12. Fisch B, Peled Y, Kaplan B, Zehavi S, Neri A (1996) Abdominal pregnancy following in vitro fertilization in a patient with previous bilateral salpingectomy. Obstet Gynecol 88(4): 642-643.

13. Chen CD, Chen SU, Chao KH, Wu MY, Ho HN, et al. (1998) Cornual pregnancy after IVF-ET. A report of three cases. J Reprod Med 43(4): 393-396.

14. Dmowski WP, Rana N, Ding J, Wu WT (2002) Retroperitoneal subpancreatic ectopic pregnancy following in vitro fertilization in a patient with previous bilateral salpingectomy: how did it get there? J Assist Reprod Genet 19(2): 90-93.

15. Cormio G, Santamato S, Putignano G, Bettocchi S, Pascazio F (2003) Concomitant abdominal and intrauterine pregnancy after in vitro fertilization in a woman with bilateral salpingectomy. A case report. J Reprod Med 48(9): 747-749.

16. Hsu CC, Yang TT, Hsu CT (2005) Ovarian pregnancy resulting from cornual fistulae in a woman who had undergone bilateral salpingectomy. Fertil Steril 83(1): 205-207. 
17. Cruciani L, Gerli S, Baiocchi G, Clerici G, Antonelli C (2011) Ovarian pregnancy after in vitro fertilisation in a woman with previous bilateral salpingectomy. J Obstet Gynaecol 31(3): 270-271.

18. Marion LL, Meeks GR (2012) Ectopic pregnancy: history, incidence, epidemiology, and risk factors. Clin Obstet Gynecol 55(2): 376-386.

19. Yovich JL, Turner SR, Murphy AJ (1985) Embryo transfer technique as a cause of ectopic pregnancies in in-vitro fertilization. Fertil Steril 44: 318-321.

20. Chin HY, Chen FP, Wang CJ, Shui LT, Liu YH, et al. (2004) Heterotopic pregnancy after in vitro fertilization-embryo transfer. Int J Gynaecol Obstet 86(3): 411-416.

21. Agarwal SK, Wisot AL, Garzo G et al. (1996) Cornual pregnancies in patients with prior salpingectomy undergoing in vitro fertilization and embryo transfer. Fertil Steril 65: 659-660.

22. Chang CC, Wu TH, Tsai HD, Lo HY (1998) Bilateral simultaneous tubal sextuplets: pregnancy after in-vitro fertilization--embryo transfer following salpingectomy. Hum Reprod 13(3): 762-765.

23. Nabeshima H, Nishimoto M, Utsunomiya H, Arai M, Ugajin T, et al. (2010) Total laparoscopic conservative surgery for an intramural ectopic pregnancy. Diagn Ther Endosc 504062.

24. Chang Y, Jau NL, Cheng HY, Hsu SC, Tsai EM (2003) An unexpected quadruplet heterotopic pregnancy after bilateral salpingectomy and replacement of three embryos. Fertil Steril 80(1): 218-220.

25. Chan LY, Yuen PM (2003) Successful treatment of ruptured interstitial pregnancy with laparoscopic surgery. A report of 2 cases. J Reprod Med 48(7): 569-571.

26. Lau S, Tulandi T (1999) Conservative medical and surgical management of interstitial ectopic pregnancy. Fertil Steril 72: 207-215.

27. Clasen K, Camus M, Tournaye H, Devroey P (1997) Ectopic pregnancy: let's cut! Strict laparoscopic approach to 194 consecutive cases and review of literature on alternatives. Hum Reprod 12(3): 596-601.

28. Barnhart K, Spandorfer S, Coutifaris C (1997) Medical treatment of interstitial pregnancy: A report of three unsuccessful cases. J Reprod Med 42(8): 521-524.

29. Sowter M, Farquhar C, Gudex G (2001) An economic evaluation of single dose systemic methotrexate and laparoscopic surgery for the treatment of unruptured ectopic pregnancy. Br J Obstet Gynaecol 108: 204-212.

30. Mol B, Hajenius P, Engelsbel S, Ankum W, Hemrika D, et al. (1999) Treatment of tubal pregnancy in the Netherlands: an economic comparison of systemic methotrexate administration and laparoscopic salpingostomy. Am J Obstet Gynecol 181(4): 945-951.
31. The management of tubal pregnancy. RCOG Guideline No. 21. May 2004 Reviewed 2010

32. Diagnosis and Management of Ectopic Pregnancy. Green-top Guideline No. 21 RCOG/AEPU Joint Guideline | November 2016

33. Yao M, Tulandi T (1997) Current status of surgical and nonsurgical management of ectopic pregnancy. Fertil Steril 67: 421-433.

34. Sowter M, Frappell J (2002) The role of laparoscopy in the management of ectopic pregnancy. Rev Gynaecol Practice 2: 73-82.

35. Garavaglia E, Quaranta L, Redaelli A, Gabriella Colombo, Federica Pasi, et al. (2012) Interstitial Pregnancy after In Vitro Fertilization and Embryo Transfer Following Bilateral Salpingectomy: Report of Two Cases and Literature Review. Int J Fertil Steril 6(2): 131-134.

36. Shavit T, Einat PS, Eylon L, Ofer F, Adrian E (2013) Unusual case of recurrent heterotopic pregnancy after bilateral salpingectomy and literature review. RBM Online 26(1): 59-61.

37. Bahareh Samiei-Sarir, Christopher Diehm (2013) Recurrent Ectopic Pregnancy in the Tubal Remnant after Salpingectomy. Case Rep Obstet Gynecol 2013: 753269.

38. Maruthini D and Sharma V (2013) A Case of Live Birth after Uterine Reconstruction for Recurrent Cornual Ectopic Pregnancy following IVF Treatment. Case Rep Obstet Gynecol 2013: 625261.

39. Nishida M, Miyamoto Y, Kawano Y, Takebayashi K, Narahara H, et al. (2015) A case of successful laparoscopic surgery for tubal stump pregnancy after tubectomy. Clin Med Insights Case Rep 8: 1-4.

40.Xu Y, Lu Y, Chen H, Li D, Zhang J, et al. (2016) Heterotopic pregnancy after in vitro fertilizitation and embryo transfer after bilateral total salpingectomy/tubal ligation.Case report and literature review. J Minim Invasive Gynecol 23: 338-345.

41. Souza C, Dullius T, Peters R, Genro V, Cunha-Filho JS (2018) Importance of a making precocious diagnostic and implementing treatment of the ectopic pregnancy in the salpingectomy stump. European Journal of Obstetrics \& Gynecology and Reproductive Biolog 223: 141-142.

42. Seshadri, Shirley P, Jaiganesh T, Uchil D, Jolaoso A (2010) In vitro fertilisation and embryo transfer for bilateral salpingectomies results in a ruptured ovarian ectopic pregnancy due to a tubal stump fistula: a case report and review of the literature. BMJ Case Rep 2010: bcr09.2009.2291.

43. Sadia Khandaker, Pranav Chitkara, Eric Cochran, Jed Cutler (2015) An Ovarian Pregnancy in a Patient with a History of Bilateral Salpingectomies: A Rare Case. Case Reports in Obstetrics and Gynecology 2015: Article ID 740376.

\section{ISSN: 2574-1241}

DOI: $10.26717 / B J S T R .2018 .10 .002026$

Chiara Di Tucci. Biomed J Sci \& Tech Res

cC (i) This work is licensed under Creative

This work is licensed under Creative
Commons Attribution 4.0 License

Submission Link: https://biomedres.us/submit-manuscript.php

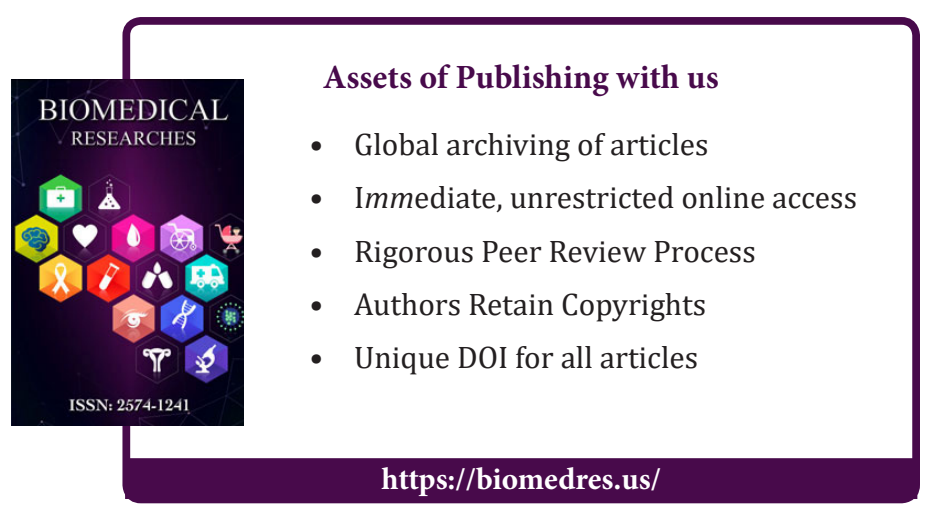

Cite this article: Di Tucci C, Schiavi Michele C, Iacobelli V, Donfrancesco C, Piccioni Maria G, Perniola Ga, Muzii L, Benedetti Panici P. Tubal Stump Pregnancy in ART Patients Two cases of ectopic stump pregnancy after IVF-ET. Biomed J Sci\&Tech Res 10(5)-2018. BJSTR. MS.ID.002026. 